\title{
Microbial Assay of The Waterborne Pathogen on Supplied Drinking Water in Gopalganj Area, Bangladesh and its Future Effect
}

\author{
Md. Imran Hossain ${ }^{1 *}$, Md Sarafat Ali $^{1}$, Md Shariful Islam ${ }^{2}$ \\ ${ }^{1}$ Department of Biotechnology and Genetic Engineering, Bangabandhu Sheikh Mujibur Rahman Science and \\ Technology University, Gopalganj-8100, Bangladesh. \\ ${ }^{2}$ Department of Biology, University of Kentucky, Lexington, United States
}

*Correspondence E-mail : mdimranhossain@bsmrstu.edu.bd

\begin{abstract}
Around $60 \%$ of water constitute the human body if about $2 \%$ of the body's water content drop anyone dehydration must have a remarkable effect. Studies show that the loss of body water can break many aspects of brain function. About Eight 8-ounce $(237-\mathrm{mL})$ glasses of water always consult by the physician for a sound person. But unfortunately, If this drinking water becomes impure it affects to develop the various vital dysfunction in our body. Infrequent bowel actions and trouble passing footrest, brain associate dysfunction along with familiar waterborne infections such as looseness, polio, diarrhoea and meningitis are the common conditions that arise for the water-borne pathogen in water.

Gopalganj is a town in Gopalgonj District belonging to the Dhaka Division of Bangladesh. According to the census(cf) of 2011-03-15, 53778 individuals are living here from the divergent profession. For geographical reasons the most of the area specially Gopalganj town along with Gobra, Ghonapra, Tungipara where most government institutions are located the groundwater is not suitable for drinking as Iron and Arsenic are the supremacy amount. That's why this is the common scenery of these areas to use drinking water jar for the purpose of safe water. For this reason here have already found about 10-15 drinking water jar supplier company.

In this research, we performed the microbiological assay to observe the presence or absence of water-born pathogen on these drinking water containing the water jar along with the morphological characteristics of these pathogens. In point of fact, we found that there is 3 to 6 type of microbes are present in this water. Among these pathogens, there are the supremacy of gram-positive bacteria than gram-negative bacteria along with some moulds co-exist on these microbiomes.
\end{abstract}

Keywords: Drinking water jar; Microbial biome; Disease; Gopalganj

\section{Introduction}

Drinking water remarked as safe water that use to drink along with food preparation. At least every day about Eight 8-ounce (237-mL) glasses of water always should take for a sound person that maintains the physical performance (Paik et al. 2009), brain function and energy level (Lawrence et al. 2012) and keep the role in all metabolic function in an individual body. Although water a generative element can also act be a life-taking poisonous component. Approximately $3.1 \%$ of total deaths in the world are due to contaminated poor quality and unsanitary water (Hunter et al. 2008). Diarrhoea (WHO, 
1993), Cholera CDCP, 2015), E. coli Infection(Bentley \& Meganathan 1982), Typhoid fever (Wain et al. 2015) etc are the common waterborne pathogen diseases in the world these take much to live in every year and most of the waterborne pathogen enters into the body by drinking water.

Gopalganj is one of the well-known districts of the Dhaka division in Bangladesh where 53778 peoples are living here (Adhikary R. 2012). In this area, water is very contaminated with iron and arsenic for its geographical region. Thus, almost every people take drinking water jar from the various supplier as safe water for their food preparation and drink. Approximately 10-15 company founded as a supplier of a drinking water jar. They take 35 to 40 taka per jar. But unfortunately, this water contains a large number of microbes.

For the purpose of test of the hygiene of these drinking water jar, we studied three samples of water containing in the drinking water jar randomly from all supplier in this location. We performed a microbiological experiment to recognise the presence and absence of microbes along with morphological characteristics.

In this study, we found there is 6-10 type of different microbial colony present on each water sample. If we don't aware and take the proper necessary steps to prevent this taking of microbially contaminated drinking water, we have to pay with regret very soon.

\section{Materials and Methods}

Three 500 micro L. water sample from randomly selected three suppliers drinking water jar, lab types of equipment these need to perform bacterial culture and gram staining.

\section{Procedure}

500 ul water sample was collected from randomly selected three drinking water jar by a 1000 ul size autoclaved Eppendorf tube. Then we gently transferred these sample in the lab and spread on nutrient solid media into laminar airflow cabinet. After spreading these three media containing each sample incubated overnight. The next day we got a mixed colony on each plate and then transferred the pure colony from the mother plate. After the next day, we got a pure colony and then we performed gram staining to determine the gram-positive and negative assay. Besides this work, we transferred each pure colony on the EMB agar plate to identify fungi. Then the next day we got some fungi on each EMB plate that grew to supremacy over bacteria.

\section{Results}

We got about 3, 5, 6 microbial colonies on each plate fig $1,2,3$. Then we transfer pure colony to each plate from these three mix colony plate and got 12 plates. After gram staining, we differentiate between positive and negative bacteria. (Figure 1).

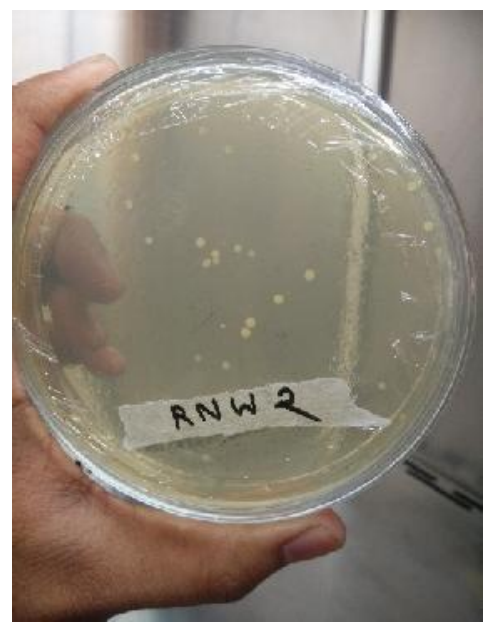

A

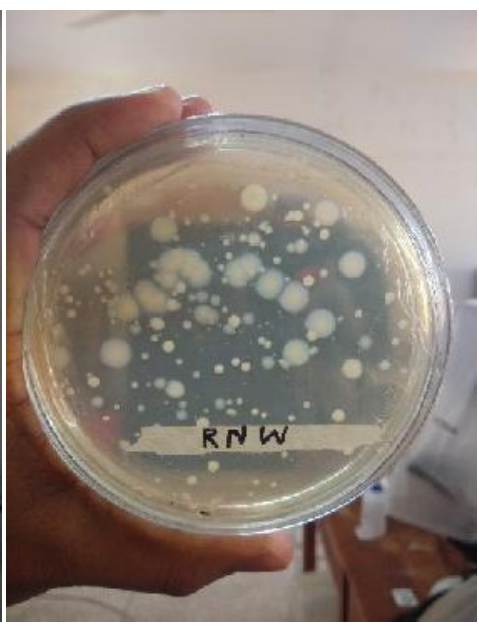

$B$

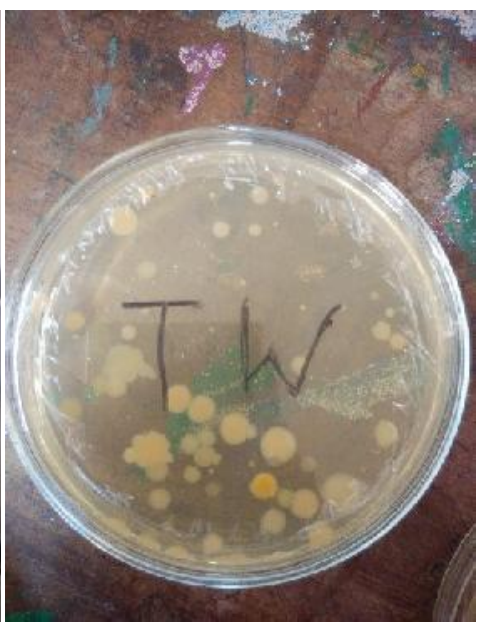

C

Figure 1: Sample growth after 24 hours of incubation (Water jar supplier 1-A, Water jar supplier 2-B and Water jar supplier 3-C) 


\section{Discussion}

Around $3.6 \%$ of disability-adjusted life year) global burden of disease and 1.5 million human deaths occur annually for waterborne diseases(WHO 2014). Gut-associated microbes also influenced by unigene water and occur many diseases for their imbalance condition (Hossain et al. 2020). On March 30, 2004, Columbia exposed a report "MMWR dispatch" on tap water microbiome these are associated with much death in the United States(CDC, 2017). Every year there are a lot of individuals who lose their lives to these waterborne pathogens by drinking or using unhygienic water.

In Gopalganj there is a terrible condition of groundwater as there are too much amount iron and arsenic contained. Most people take supplier drinking water jar as safe water rather than groundwater. But unfortunately, these supplier drinking water are not safe from the waterborne microbiome. We collect three sample of water randomly from a different supplier and got there are a lot amount microbial colony. Specially gram-negative bacteria supremacy on other types of bacteria. Fungi also present on these samples these are responsible for various human skin diseases.

Therefore, In Gopalganj town area should take steps to prevent taking these contaminated unigene water. Otherwise, it is sure to suffer much very soon.

Two species of ostracoda viz. cypris $s p$ and cyprinotus $s p$ were observed during this study.

\section{References}

Burden of disease and cost-effectiveness estimates. World Health Organization. Archived from the original on February 13, 2014. Retrieved April 5, 2014.

Cholera - Vibrio cholera infection Information for Public Health \& Medical Professionals". Centers for Disease Control and Prevention. January 6, 2015. Archived from the original on 20 March 2015. Retrieved 17 March 2015.

Waterborne Disease \& Outbreak Surveillance Reporting | Water-related Topics | Healthy Water | CDC". www.cdc.gov. 2017-10-16. Retrieved 201812-07. This article incorporates text from this source, which is in the public domain.
Present study revealed the occurance of cypris $s p$ throughout the year but cyprinotus was decreased in winter and not observed in rainy days. The population of ostracods was maximum in summer i.e. from march to June and decreased during winter from December to February.

\section{Conclusion}

Safe and immediately usable water is essential for public health, whether it is utilised for drinking, household use, food production or other necessary purposes. Purified water supply and hygiene, and better supervision of water supplies, can encourage countries' economic growth and can offer greatly to poverty reduction. In Gopalganj its an urgent need to be aware of taking supplier drinking water for sound health. These microbial biome in supplier water are responsible for various water-related diseases. The purifying technique should be established in everywhere to get immediately usable water for daily needs.

\section{Acknowledgments}

The authors would like to thank the Department of Biotechnology and Genetic Engineering, Bangabandhu Sheikh Mujibur Rahman Science and Technology University, Gopalganj, Bangladesh for supporting and discussing this research article.

\section{Conflicts of Interest}

The authors declare no conflict of interest.

Adhikari, Rabindranath (2012). Gopalganj District. In Islam, Sirajul; Jamal, Ahmed A. (eds.). Banglapedia: National Encyclopedia of Bangladesh (Second ed.). Asiatic Society of Bangladesh

Bentley R, Meganathan R (September 1982). "Biosynthesis of vitamin $\mathrm{K}$ (menaquinone) in bacteria". Microbiological Reviews. 46 (3): 241-80. doi:10.1128/MMBR.46.3.241-280.1982. PMC 281544. PMID 6127606

Hossain, M. I., Islam, R., Mimi, S., Jewel, Z., \& Haider, U. (2020). Gut Microbiota Gut Microbiota: Succinct Overview of Impacts on Human Physique and Current Research Status with Future Aspects. International Journal of Advancement in Life Sciences Research, 3(2), 1-10. Retrieved 
Int J Adv Life Sci Res. Volume 4(2)01-04

fromhttps://ijalsr.org/index.php/journal/article/view/8 1

Hunter, P. R., Colford, J. M., LeChevallier, M. W., Binder, S., \& Berger, P. S. (2001). Waterborne diseases. Emerging infectious diseases, 7(3 Suppl), 544.https://doi.org/10.3201/eid0707.017723

Lawrence E. Armstrong, Matthew S. Ganio, Douglas J. Casa, Elaine C. Lee, Brendon P. McDermott, Jennifer F. Klau, Liliana Jimenez, Laurent Le Bellego, Emmanuel Chevillotte, Harris R. Lieberman, Mild Dehydration Affects Mood in Healthy Young Women, The Journal of Nutrition, Volume 142, Issue 2, February 2012, Pages 382388,https://doi.org/10.3945/jn.111.142000

Paik IY, Jeong MH, Jin HE, Kim YI, Suh AR, Cho $\mathrm{SY}$, Roh HT, Jin $\mathrm{CH}$, Suh $\mathrm{SH}$. Fluid replacement following dehydration reduces oxidative stress during recovery. BiochemBiophys Res Commun. 2009 May 22;383(1):103-7. DOI: 10.1016/j.bbrc.2009.03.135. Epub 2009 Apr 1. PMID: 19344695.
Wain J, Hendriksen RS, Mikoleit ML, Keddy KH, Ochiai RL (March 2015). "Typhoid fever". Lancet. 385 (9973): 1136-45. doi:10.1016/s01406736(13)62708-7. PMID 25458731. S2CID 2409150

World Health Organization. (1993). Guidelines for drinking-water quality. (Fourth edition incorporating the first addendum ed.). World Health Organization. https://apps.who.int/iris/handle/10665/ 254637. 